4

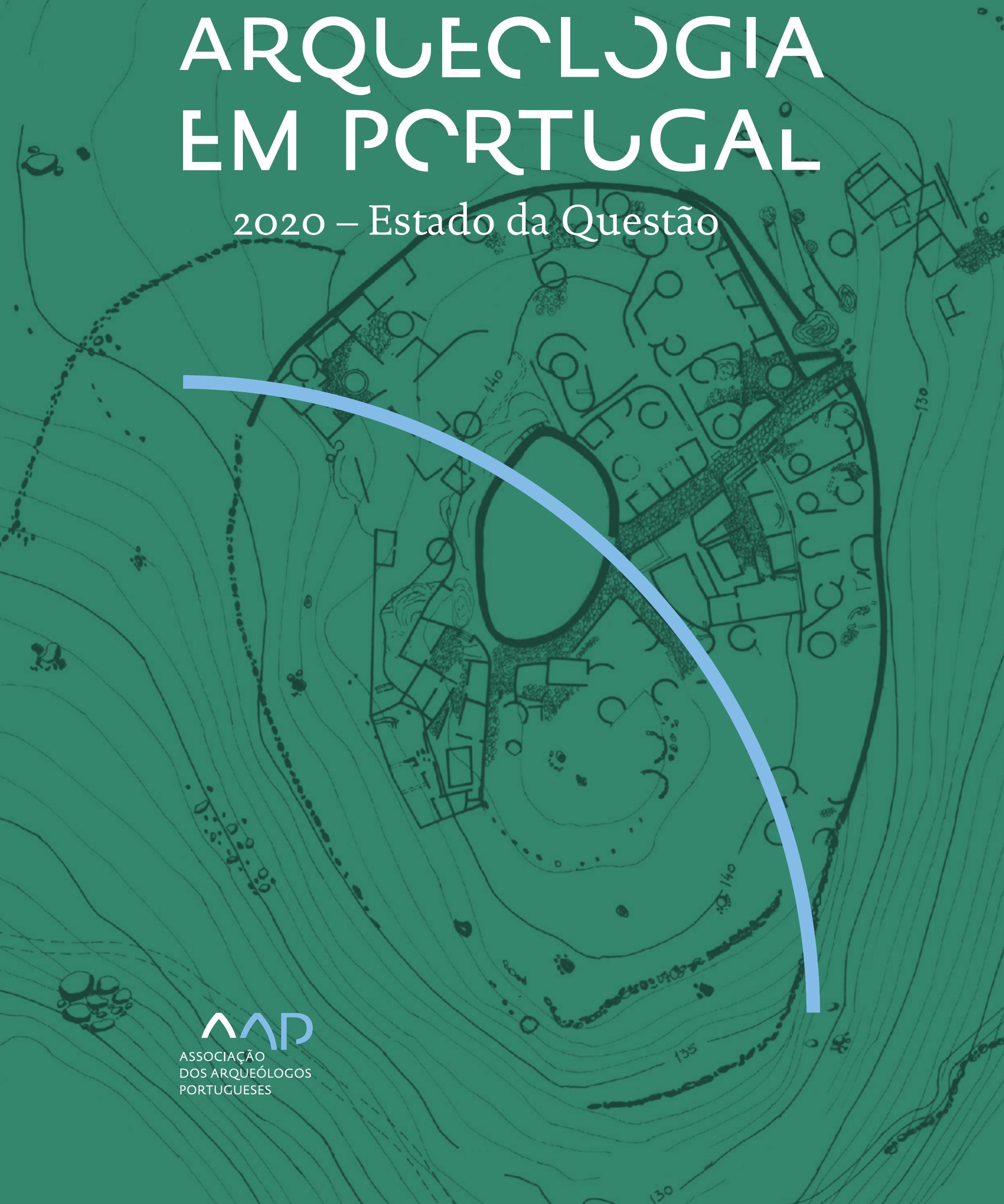


Coordenação editorial: José Morais Arnaud, César Neves e Andrea Martins Design gráfico: Flatland Design

AAP - ISBN: 978-972-9451-89-8

CITCEM - ISBN: 978-989-8970-25-1

Associação dos Arqueólogos Portugueses e CITCEM

Lisboa, 2020

O conteúdo dos artigos é da inteira responsabilidade dos autores. Sendo assim a Associação dos Arqueólogos Portugueses declina qualquer responsabilidade por eventuais equívocos ou questões de ordem ética e legal.

Desenho de capa:

Planta do castro de Monte Mozinho (Museu Municipal de Penafiel).

\section{$\hat{\wedge} \mathrm{P}$}

DOS ARQUEÓLOGOS PORTUGUESES

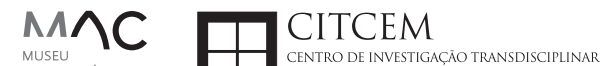
MUSEU
ARQUELLÓGICO
DO CARMO
U.PORTO

FLUP FACULDADE DE LETRAS
UNIVERSIDADE DO PORTO

Apoio

EC para a Ciência 


\section{Índice}

15 Prefácio

José Morais Arnaud

\section{Historiografia e Teoria}

17 Território, comunidade, memória e emoção: a contribuição da história da arqueologia (algumas primeiras e breves reflexões)

Ana Cristina Martins

25 Como descolonizar a arqueologia portuguesa?

Rui Gomes Coelho

41 Arqueologia e Modernidade: uma revisitação pessoal e breve de alguns aspetos da obra homónima de Julian Thomas de 2004

Vítor Oliveira Jorge

57 Dados para a História das Mulheres na Arqueologia portuguesa, dos finais do século XIX aos inícios do século XX: números, nomes e tabelas

Filipa Dimas / Mariana Diniz

73 Retractos da arqueologia portuguesa na imprensa: (in)visibilidades no feminino

Catarina Costeira / Elsa Luís

85 Arqueologia e Arqueólogos no Norte de Portugal Jacinta Bugalhão

101 Vieira Guimarães (1864-1939) e a arqueologia em Tomar: uma abordagem sobre o território e as gentes

João Amendoeira Peixoto / Ana Cristina Martins

115 Os memoráveis? A arqueologia algarvia na imprensa nacional e regional na presente centúria (2001-2019): características, visões do(s) passado(s) e a arqueologia

enquanto marca

Frederico Agosto / João Silva

129 A Evolução da Arqueologia Urbana e a Valorização Patrimonial no Barlavento Algarvio: Os casos de Portimão e Silves

Artur Mateus / Diogo Varandas / Rafael Boavida

\section{Gestão, Valorização e Salvaguarda do Património}

145 O Caderno Reivindicativo e as condições de trabalho em Arqueologia Miguel Rocha / Liliana Matias Carvalho / Regis Barbosa / Mauro Correia / Sara Simões / Jacinta Bugalhão / Sara Brito / Liliana Veríssimo Carvalho / Richard Peace / Pedro Peça / Cézer Santos

155 Os Estudos de Impacte Patrimonial como elemento para uma estratégia sustentável de minimização de impactes no âmbito de reconversões agrícolas Tiago do Pereiro

165 Salvaguarda de Património arqueológico em operações florestais: gestão e sensibilização Filipa Bragança / Gertrudes Zambujo / Sandra Lourenço / Belém Paiva / Carlos Banha / Frederico Tatá Regala / Helena Moura / Jacinta Bugalhão / João Marques / José Correia / Pedro Faria / Samuel Melro

179 Os valores do Património: uma investigação sobre os Sítios Pré-históricos de Arte Rupestre do Vale do Rio Côa e de Siega Verde José Paulo Francisco 
189 Conjugando recursos arqueológicos e naturais para potenciar as visitas ao Geoparque Litoral de Viana do Castelo (Noroeste de Portugal)

Hugo A. Sampaio / Ana M.S. Bettencourt / Susana Marinho / Ricardo Carvalhido

203 Áreas de Potencial Arqueológico na Região do Médio Tejo: Modelo Espacial Preditivo Rita Ferreira Anastácio / Ana Filipa Martins / Luiz Oosterbeek

223 Património Arqueológico e Gestão Territorial: O contributo da Arqueologia para a revisão do PDM de Avis

Ana Cristina Ribeiro

237 A coleção arqueológica do extinto Museu Municipal do Porto - Origens, Percursos e Estudos

Sónia Couto

251 Valpaços - uma nova carta arqueológica

Pedro Pereira / Maria de Fátima Casares Machado

263 Arqueologia na Cidade de Peniche

Adriano Constantino / Luís Rendeiro

273 Arqueologia Urbana: a cidade de Lagos como caso de Estudo Cátia Neto

285 Estratégias de promoção do património cultural subaquático nos Açores. O caso da ilha do Faial

José Luís Neto / José Bettencourt / Luís Borges / Pedro Parreira

297 Carta Arqueológica da Cidade Velha: Uma primeira abordagem

Jaylson Monteiro / Nireide Tavares / Sara da Veiga / Claudino Ramos / Edson Brito /

Carlos Carvalho / Francisco Moreira / Adalberto Tavares

311 Antropologia Virtual: novas metodologias para a análise morfológica e funcional Ricardo Miguel Godinho / Célia Gonçalves

\section{Didáctica da Arqueologia}

327 Como os projetos de Arqueologia podem contribuir para uma comunidade culturalmente mais consciente Alexandra Figueiredo / Claúdio Monteiro / Adolfo Silveira / Ricardo Lopes

337 Educação Patrimonial - Um cidadão esclarecido é um cidadão ativo! Ana Paula Almeida

351 A aproximação da Arqueologia à sala de aula: um caso de estudo no $3^{\circ}$ ciclo do Ensino Básico Luís Serrão Gil

363 Arqueologia 3.o - Pensar e comunicar a Arqueologia para um futuro sustentável Mónica Rolo

377 “Conversa de Arqueólogos" - Divulgar a Arqueologia em tempos de Pandemia Diogo Teixeira Dias

389 Escola Profissional de Arqueologia: desafios e oportunidades Susana Nunes / Dulcineia Pinto / Júlia Silva / Ana Mascarenhas

399 Os Museus de Arqueologia e os Jovens: a oferta educativa para o público adolescente Beatriz Correia Barata / Leonor Medeiros

411 O museu universitário como mediador entre a ciência e a sociedade: o exemplo da secção de arqueologia no Museu de História Natural e da Ciência da Universidade do Porto (MHNC-UP)

Rita Gaspar 
421 Museu de Lanifícios: Real Fábrica de Panos. Atividades no âmbito da Arqueologia Beatriz Correia Barata / Rita Salvado

427 Arqueologia Pública e o caso da localidade da Mata (Torres Novas) Cláudia Manso / Ana Rita Ferreira / Cristiana Ferreira / Vanessa Cardoso Antunes

431 Do sítio arqueológico ao museu: um percurso (também) didático Lídia Fernandes

447 Estão todos convidados para a Festa! E para dançar também... O projecto do Serviço Educativo do Museu Arqueológico do Carmo na $5^{\underline{a}}$ Edição da Festa da Arqueologia Rita Pires dos Santos

459 O “Clã de Carenque”, um projeto didático de arqueologia Eduardo Gonzalez Rocha

469 Mediação cultural: peixe que puxa carroça nas Ruínas Romanas de Troia Inês Vaz Pinto / Ana Patrícia Magalhães / Patrícia Brum / Filipa Santos

481 Didática Arqueológica, experiências do Projeto Mértola Vila Museu Maria de Fátima Palma / Clara Rodrigues / Susana Gómez / Lígia Rafael

\section{Arte Rupestre}

497 Os inventários de arte rupestre em Portugal Mila Simões de Abreu

513 O projeto FIRST-ART - conservação, documentação e gestão das primeiras manifestações de arte rupestre no Sudoeste da Península Ibérica: as grutas do Escoural e Maltravieso Sara Garcês / Hipólito Collado / José Julio García Arranz / Luiz Oosterbeek / António Carlos Silva / Pierluigi Rosina / Hugo Gomes / Anabela Borralheiro Pereira / George Nash / Esmeralda Gomes / Nelson Almeida / Carlos Carpetudo

523 Trabalhos de documentação de arte paleolítica realizados no âmbito do projeto PalæoCôa André Tomás Santos / António Fernando Barbosa / Luís Luís / Marcelo Silvestre / Thierry Aubry

537 Imagens fantasmagóricas, silhuetas elusivas: as figuras humanas na arte do Paleolítico Superior da região do Côa Mário Reis

$55^{1}$ Os motivos zoomórficos representados nas placas de tear de Vila Nova de São Pedro (Azambuja, Portugal) Andrea Martins / César Neves / José M. Arnaud / Mariana Diniz

571 Arte Rupestre do Monte de Góios (Lanhelas, Caminha). Síntese dos resultados dos trabalhos efectuados em 2007-2009 Mário Varela Gomes

599 Gravuras rupestres de barquiformes no Monte de S. Romão, Guimarães, Noroeste de Portugal Daniela Cardoso

613 Círculos segmentados gravados na Bacia do Rio Lima (Noroeste de Portugal): contributos para o seu estudo Diogo Marinho / Ana M.S. Bettencourt / Hugo Aluai Sampaio

631 Equídeos gravados no curso inferior do Rio Mouro, Monção (NW Portugal). Análise preliminar Coutinho, L.M. / Bettencourt, A.M.S / Sampaio, Hugo A.S

645 Paletas na Arte Rupestre do Noroeste de Portugal. Inventário preliminar Bruna Sousa Afonso / Ana M. S. Bettencourt / Hugo A. Sampaio 


\section{Pré-História}

661 O projeto Miño/Minho: balanço de quatro anos de trabalhos arqueológicos Sérgio Monteiro-Rodrigues / João Pedro Cunha-Ribeiro / Eduardo Méndez-Quintas / Carlos Ferreira / Pedro Xavier / José Meireles / Alberto Gomes / Manuel Santonja / Alfredo Pérez-González

677 A ocupação paleolítica da margem esquerda do Baixo Minho: a indústria lítica do sítio de Pedreiras 2 (Monção, Portugal) e a sua integração no contexto regional Carlos Ferreira / João Pedro Cunha-Ribeiro / Sérgio Monteiro-Rodrigues / Eduardo Méndez-Quintas / Pedro Xavier / José Meireles / Alberto Gomes / Manuel Santonja / Alfredo Pérez-González

693 O sítio acheulense do Plistocénico médio da Gruta da Aroeira Joan Daura / Montserrat Sanz / Filipa Rodrigues / Pedro Souto / João Zilhão

703 As sociedades neandertais no Barlavento algarvio: modelos preditivos com recurso aos SIG

Daniela Maio

715 A utilização de quartzo durante o Paleolítico Superior no território dos vales dos rios Vouga e Côa

Cristina Gameiro / Thierry Aubry / Bárbara Costa / Sérgio Gomes / Luís Luís / Carmen Manzano / André Tomás Santos

733 Uma perspetiva diacrónica da ocupação do concheiro do Cabeço da Amoreira (Muge, Portugal) a partir da tecnologia lítica Joana Belmiro / João Cascalheira / Célia Gonçalves

745 Novos dados sobre a Pré-história Antiga no concelho de Palmela. A intervenção arqueológica no sítio do Poceirão I

Michelle Teixeira Santos

757 Problemas em torno de Datas Absolutas Pré-Históricas no Norte do Alentejo Jorge de Oliveira

771 Povoamento pré-histórico nas áreas montanhosas do NO de Portugal: o Abrigo 1 de Vale de Cerdeira Pedro Xavier / José Meireles / Carlos Alves

783 Apreciação do povoamento do Neolítico Inicial na Baixa Bacia do Douro. A Lavra I (Serra da Aboboreira) como caso de estudo Maria de Jesus Sanches

797 O Processo de Neolitização na Plataforma do Mondego: os dados do Sector C do Outeiro dos Castelos de Beijós (Carregal do Sal)

João Carlos de Senna-Martinez / José Manuel Quintã Ventura / Andreia Carvalho / Cíntia Maurício

823 Novos trabalhos na Lapa da Bugalheira (Almonda, Torres Novas) Filipa Rodrigues / Pedro Souto / Artur Ferreira / Alexandre Varanda / Luís Gomes / Helena Gomes / João Zilhão

837 A pedra polida e afeiçoada do sítio do Neolítico médio da Moita do Ourives (Benavente, Portugal)

César Neves

857 Casal do Outeiro (Encarnação, Mafra): novos contributos para o conhecimento do povoamento do Neolítico final na Península de Lisboa.

Cátia Delicado / Carlos Maneira e Costa / Marta Miranda / Ana Catarina Sousa

873 Stresse infantil, morbilidade e mortalidade no sítio arqueológico do Neolítico Final/ Calcolítico ( $4^{\circ}$ e $3^{\circ}$ milénio a.C.) do Monte do Carrascal 2 (Ferreira do Alentejo, Beja) Liliana Matias de Carvalho / Sofia N. Wasterlain 
885 Come together: O Conjunto Megalítico das Motas (Monção, Viana do Castelo) e as expressões Campaniformes do Alto Minho Ana Catarina Basílio / Rui Ramos

899 Trabalhos arqueológicos no sítio Calcolítico da Pedreira do Poio Carla Magalhães / João Muralha / Mário Reis / António Batarda Fernandes

913 O sítio arqueológico de Castanheiro do Vento. Da arquitectura do sítio à arquitectura de um território João Muralha Cardoso

925 Estudo zooarqueológico das faunas do Calcolítico final de Vila Nova de São Pedro (Azambuja, Portugal): Campanhas de 2017 e 2018 Cleia Detry / Ana Catarina Francisco / Mariana Diniz / Andrea Martins / César Neves / José Morais Arnaud

943 As faunas depositadas no Museu Arqueológico do Carmo provenientes de Vila Nova de São Pedro (Azambuja): as campanhas de 1937 a 1967 Ana Catarina Francisco / Cleia Detry / César Neves / Andrea Martins / Mariana Diniz / José Morais Arnaud

959 Análise funcional de material lítico em sílex do castro de Vila Nova de S. Pedro (Azambuja, Portugal): uma primeira abordagem Rafael Lima

971 O recinto da Folha do Ouro 1 (Serpa) no contexto dos recintos de fossos calcolíticos alentejanos

António Carlos Valera / Tiago do Pereiro / Pedro Valério / António M. Monge Soares

\section{Proto-História}

987 Produção de sal marinho na Idade do Bronze do noroeste Português. Alguns dados para uma reflexão

Ana M. S. Bettencourt / Sara Luz / Nuno Oliveira / Pedro P. Simões / Maria Isabel C. Alves / Emílio Abad-Vidal

1001 A estátua-menir do Pedrão ou de São Bartolomeu do Mar (Esposende, noroeste de Portugal) no contexto arqueológico da fachada costeira de entre os rios Neiva e Cávado Ana M. S. Bettencourt / Manuel Santos-Estévez / Pedro Pimenta Simões / Luís Gonçalves

1015 O Castro do Muro (Vandoma/Baltar, Paredes) - notas para uma biografia de ocupação da Idade do Bronze à Idade Média

Maria Antónia D. Silva / Ana M. S. Bettencourt / António Manuel S. P. Silva / Natália Félix

1031 Do Bronze Final à Idade Média - continuidades e hiatos na ocupação de Povoados em Oliveira de Azeméis João Tiago Tavares / Adriaan de Man

1041 As faunas do final da Idade do Bronze no Sul de Portugal: leituras desde o Outeiro do Circo (Beja)

Nelson J. Almeida / Íris Dias / Cleia Detry / Eduardo Porfírio / Miguel Serra

1055 A Espada do Monte das Oliveiras (Serpa) - uma arma do Bronze Pleno do Sudoeste Rui M. G. Monge Soares / Pedro Valério / Mariana Nabais / António M. Monge Soares

1065 São Julião da Branca (Albergaria-a-Velha) - Investigação e valorização de um povoado do Bronze Final

António Manuel S. P. Silva / Paulo A. P. Lemos / Sara Almeida e Silva / Edite Martins de Sá

1083 Do castro de S. João ao Mosteiro de Santa Clara: notícia de uma intervenção arqueológica, em Vila do Conde Rui Pinheiro 
1095 O castro de Ovil (Espinho), um quarto de século de investigação - resultados e questões em aberto

Jorge Fernando Salvador / António Manuel S. P. Silva

1111 O Castro de Salreu (Estarreja), um povoado proto-histórico no litoral do Entre Douro e Vouga

Sara Almeida e Silva / António Manuel S. P. Silva / Paulo A. P. Lemos / Edite Martins de Sá

1127 Castro de Nossa Senhora das Necessidades (Sernancelhe): uma primeira análise artefactual Telma Susana O. Ribeiro

${ }_{1141}$ A cividade de Bagunte. O estado atual da investigação Pedro Brochado de Almeida

1153 Zoomorfos na cerâmica da Idade do Ferro no NW Peninsular: inventário, cronologias e significado Nuno Oliveira / Cristina Seoane

1163 Vasos gregos em Portugal: diferentes maneiras de contar a história do intercâmbio cultural na Idade do Ferro

Daniela Ferreira

1175 Os exotica da necrópole da Idade do Ferro do Olival do Senhor dos Mártires (Alcácer do Sal) no seu contexto regional

Francisco B. Gomes

\section{Antiguidade Clássica e Tardia}

1191 O uso de madeira como combustível no sítio da Quinta de Crestelos (Baixo Sabor): da Idade do Ferro à Romanização Filipe Vaz / João Tereso / Sérgio Simões Pereira / José Sastre / Javier Larrazabal Galarza / Susana Cosme / José António Pereira / Israel Espi

1207 Cultivos de Época Romana no Baixo Sabor: continuidade em tempos de mudança? João Pedro Tereso / Sérgio Simões Pereira / Filipe Santos / Luís Seabra / Filipe Vaz

1221 A casa romana na Hispânia: aplicação dos modelos itálicos nas províncias ibéricas Fernanda Magalhães / Diego Machado / Manuela Martins

1235 As pinturas murais romanas da Rua General Sousa Machado, n. ${ }^{5}$ 1, Chaves José Carvalho

1243 Trás do Castelo (Vale de Mir, Pegarinhos, Alijó) - Uma exploração agrícola romana do Douro

Tony Silvino / Pedro Pereira

1255 A sequência de ocupação no quadrante sudeste de Bracara Augusta: as transformações de uma unidade doméstica Lara Fernandes / Manuela Martins

1263 Os Mosaicos com decoração geométrica e geométrico-vegetalista dos sítios arqueológicos da área do Conuentus Bracaraugustanus. Novas abordagens quanto à conservação, restauro, decoração e datação Maria de Fátima Abraços / Licínia Wrench

1277 “Casa Romana” do Castro de São Domingos (Cristelos, Lousada): Escavação, Estudo e Musealização Paulo André de P. Lemos

1291 A arqueobotânica no Castro de Guifões (Matosinhos, Noroeste de Portugal): O primeiro estudo carpológico

Luís Seabra / Andreia Arezes / Catarina Magalhães / José Varela / João Pedro Tereso 
1305 Um Horreum Augustano na Foz do Douro (Monte do Castelo de Gaia, Vila Nova de Gaia) Rui Ramos

1311 Ponderais romanos na Lusitânia: padrões, formas, materiais e contextos de utilização Diego Barrios Rodríguez

1323 Um almofariz centro-itálico na foz do Mondego

Marco Penajoia

1335 Estruturas romanas de Carnide - Lisboa Luísa Batalha / Mário Monteiro / Guilherme Cardoso

1347 O contexto funerário do sector da "necrópole NO" da Rua das Portas de S. Antão (Lisboa): o espaço, os artefactos, os indivíduos e a sua interconectividade na interpretação do passado Sílvia Loja, José Carlos Quaresma, Nelson Cabaço, Marina Lourenço, Sílvia Casimiro, Rodrigo Banha da Silva, Francisca Alves-Cardoso

${ }_{1361}$ Povoamento em época Romana na Amadora - resultados de um projeto pluridisciplinar Gisela Encarnação / Vanessa Dias

1371 A Arquitectura Residencial em Mirobriga (Santiago do Cacém): contributo a partir de um estudo de caso Filipe Sousa / Catarina Felício

${ }_{1385}$ O fim do ciclo. Saneamento e gestão de resíduos nos edifícios termais de Mirobriga (Santiago do Cacém)

Catarina Felício / Filipe Sousa

1399 Balsa, Topografia e Urbanismo de uma Cidade Portuária Vítor Silva Dias / João Pedro Bernardes / Celso Candeias / Cristina Tété Garcia

1413 No Largo das Mouras Velhas em Faro (2017): novas evidências da necrópole norte de Ossonoba e da sua ocupação medieval Ricardo Costeira da Silva / Paulo Botelho / Fernando Santos / Liliana Nunes

1429 Instrumentos de pesca recuperados numa fábrica de salga em Ossonoba (Faro) Inês Rasteiro / Ricardo Costeira da Silva / Paulo Botelho

1439 A Necrópole Romana do Eirô, Duas Igrejas (Penafiel): intervenção arqueológica de 2016 Laura Sousa / Teresa Soeiro

1457 Ritual, descarte ou afetividade? A presença de Canis lupus familiaris na Necrópole Noroeste de Olisipo (Lisboa)

Beatriz Calapez Santos / Sofia Simões Pereira / Rodrigo Banha da Silva / Sílvia Casimiro / Cleia Detry / Francisca Alves Cardoso

1467 Dinâmicas económicas em Bracara na Antiguidade Tardia Diego Machado / Manuela Martins / Fernanda Magalhães / Natália Botica

1479 Cerâmicas e Vidros da Antiguidade Tardia do Edifício sob a Igreja do Bom Jesus (Vila Nova de Gaia) Joaquim Filipe Ramos

1493 Novos contributos para a topografia histórica de Mértola no período romano e na Antiguidade Tardia Virgílio Lopes

\section{8. Época Medieval}

1511 Cerâmicas islâmicas no Garb setentrional "português": algumas evidências e incógnitas Constança dos Santos / Helena Catarino / Susana Gómez / Maria José Gonçalves / Isabel Inácio / Gonçalo Lopes / Jacinta Bugalhão / Sandra Cavaco / Jaquelina Covaneiro / Isabel Cristina Fernandes / Ana Sofia Gomes 
1525 Contributo para o conhecimento da cosmética islâmica, em Silves, durante a Idade Média Rosa Varela Gomes

1537 Yábura e o seu território - uma análise histórico-arqueológica de Évora entre os séculos VIII-XII José Rui Santos

1547 A encosta sul do Castelo de Palmela - resultados preliminares da escavação arqueológica Luís Filipe Pereira / Michelle Teixeira Santos

1559 A igreja de São Lourenço (Mouraria, Lisboa): um conjunto de silos e de cerâmica medieval islâmica

Andreia Filipa Moreira Rodrigues

1571 O registo material de movimentações populacionais no Médio Tejo, durante os séculos XII-XIII. Dois casos de "sunken featured buildings", nos concelhos de Cartaxo e Torres Novas Marco Liberato / Helena Santos / Nuno Santos

1585 O nordeste transmontano nos alvores da Idade média. Notas para reflexão Ana Maria da Costa Oliveira

1601 Sepulturas escavadas na rocha do Norte de Portugal e do Vale do Douro: primeiros resultados do Projecto SER-NPVD

Mário Jorge Barroca / César Guedes / Andreia Arezes / Ana Maria Oliveira

1619 "Portucalem Castrum Novum" entre o Mediterrâneo e o Atlântico: o estudo dos materiais cerâmicos alto-medievais do arqueossítio da rua de D. Hugo, nํ. 5 (Porto) João Luís Veloso

1627 A Alta Idade Média na fronteira de Lafões: notas preliminares sobre a Arqueologia no Concelho de Vouzela

Manuel Luís Real / Catarina Tente

1641 Um conjunto cerâmico medieval fora de portas: um breve testemunho aveirense Susana Temudo

${ }_{1651}$ Os Lóios do Porto: uma perspetiva integrada no panorama funerário da Baixa Idade Média à Época Moderna em meios urbanos em Portugal

Ana Lema Seabra

1659 O Caminho Português Interior de Santiago como eixo viário na Idade Média Pedro Azevedo

1665 Morfologia Urbana: Um exercício em torno do Castelo de Ourém André Donas-Botto / Jaqueline Pereira

1677 Intervenção arqueológica na Rua Marquês de Pombal/Largo do Espírito Santo (Bucelas, Loures)

Florbela Estêvão / Nathalie Antunes-Ferreira / Dário Ramos Neves / Inês Lisboa

1691 O Cemitério Medieval do Poço do Borratém e a espacialidade funerária na cidade de Lisboa Inês Belém / Vanessa Filipe / Vasco Noronha Vieira / Sónia Ferro / Rodrigo Banha da Silva

1705 Um Espaço Funerário Conventual do séc. XV em Lisboa: o caso do Convento de São Domingos da Cidade Sérgio Pedroso / Sílvia Casimiro / Rodrigo Banha da Silva / Francisca Alves Cardoso

\section{9. Época Moderna e Contemporânea}

1721 Arqueologia Moderna em Portugal: algumas reflexões críticas em torno da quantificação de conjuntos cerâmicos e suas inferências históricas e antropológicas Rodrigo Banha da Silva / André Bargão / Sara da Cruz Ferreira

1733 Faianças de dois contextos entre os finais do século XVI e XVIII do Palácio dos Condes de Penafiel, Lisboa

Martim Lopes / Tomás Mesquita 
1747 Um perfil de consumo do século XVIII na foz do Tejo: O caso do Mercado da Ribeira, Lisboa Sara da Cruz Ferreira / Rodrigo Banha da Silva / André Bargão

1761 Os Cachimbos dos Séculos XVII e XVIII do Palácio Mesquitela e Convento dos Inglesinhos (Lisboa)

Inês Simão / Marina Pinto / João Pimenta / Sara da Cruz Ferreira / André Bargão / Rodrigo Banha da Silva

1775 "Tomar os fumos da erua que chamão em Portugal erua sancta». Estudo de Cachimbos provenientes da Rua do Terreiro do Trigo, Lisboa

Miguel Martins de Sousa / José Pedro Henriques / Vanessa Galiza Filipe

1787 Cachimbos de Barro Caulínitico da Sé da Cidade Velha (República de Cabo Verde)

Rodrigo Banha da Silva / João Pimenta / Clementino Amaro

1801 Algumas considerações sobre espólio não cerâmico recuperado no Largo de Jesus (Lisboa) Carlos Boavida

1815 Adereços de vidro, dos séculos XVI-XVIII, procedentes do antigo Convento de Santana de Lisboa (anéis, braceletes e contas)

Joana Gonçalves / Rosa Varela Gomes / Mário Varela Gomes

1837 Da ostentação, luxo e poder à simplicidade do uso quotidiano: arqueologia e simbologia de joias e adornos da Idade Moderna Portuguesa Jéssica Iglésias

1849 Os amuletos em Portugal - dos objetos às superstições: o coral vermelho Alexandra Vieira

1865 Cerâmicas de Vila Franca de Xira nos séculos XV e XVI Eva Pires

1879 «Não passa por teu o que me pertence». Marcas de individualização associadas a faianças do Convento de Nossa Senhora de Aracoeli, Alcácer do Sal Catarina Parreira / Íris Fragoso / Miguel Martins de Sousa

1891 Cerâmica de Leiria: alguns focos de produção

Jaqueline Pereira / André Donas-Botto

1901 Os Fornos na Rua da Biquinha, em Óbidos Hugo Silva / Filipe Oliveira

1909 A casa de Pêro Fernandes, contador dos contos de D. Manuel I: o sítio arqueológico da Silha do Alferes, Seixal (século XVI) Mariana Nunes Ferreira

1921 O Alto da Vigia (Sintra) e a vigilância e defesa da costa Alexandre Gonçalves / Sandra Santos

1937 O contexto da torre sineira da Igreja de Santa Maria de Loures Paulo Calaveira / Martim Lopes

1949 A Necrópole do Hospital Militar do Castelo de São Jorge e as práticas funerárias na Lisboa de Época Moderna Susana Henriques / Liliana Matias de Carvalho / Ana Amarante / Sofia N. Wasterlain

1963 SAND - Sarilhos Grandes Entre dois Mundos: o adro da Igreja e a Paleobiologia dos ossos humanos recuperados

Paula Alves Pereira / Roger Lee Jesus / Bruno M. Magalhães

1975 Expansão urbana da vila de Cascais no século XVII e XVIII: a intervenção arqueológica na Rua da Vitória no 15 a 17

Tiago Pereira / Vanessa Filipe

1987 Novos dados para o conhecimento do Urbanismo de Faro em época Moderna Ana Rosa 
1995 Um exemplo de Arqueologia Urbana em Alcoutim: o Antigo Edifício dos CTT Marco Fernandes / Marta Dias / Alexandra Gradim / Virgílio Lopes / Susana Gómez Martínez

2007 Palácio dos Ferrazes (Rua das Flores/Rua da Vitória, Porto): a cocheira de Domingos Oliveira Maia

Francisco Raimundo

2021 As muitas vidas de um edifício urbano: História, Arqueologia e Antropologia no antigo Recreatório Paroquial de Penafiel Helena Bernardo / Jorge Sampaio / Marta Borges

2035 O convento de Nossa Senhora da Esperança de Ponta Delgada: o contributo da arqueologia para o conhecimento de um monumento identitário João Gonçalves Araújo / N’Zinga Oliveira

2047 Arqueologia na ilha do Corvo... em busca da capela de Nossa Senhora do Rosário Tânia Manuel Casimiro / José Luís Neto / Luís Borges / Pedro Parreira

2059 Perdidos à vista da Costa. Trabalhos arqueológicos subaquáticos na Barra do Tejo Jorge Freire / José Bettencourt / Augusto Salgado

2071 Arqueologia marítima em Cabo Verde: enquadramento e primeiros resultados do projecto CONCHA

José Bettencourt / Adilson Dias / Carlos Lima / Christelle Chouzenoux / Cristóvão Fonseca / Dúnia Pereira / Gonçalo Lopes / Inês Coelho / Jaylson Monteiro / José Lima / Maria Eugénia Alves / Patrícia Carvalho / Tiago Silva

2085 Trabalhos arqueológicos na Cidade Velha (Ribeira Grande de Santiago, Cabo Verde): reflexões sobre um projecto de investigação e divulgação patrimonial André Teixeira / Jaylson Monteiro / Mariana Mateus / Nireide Tavares / Cristovão Fonseca / Gonçalo C. Lopes / Joana Bento Torres / Dúnia Pereira / André Bargão / Aurélie Mayer / Bruno Zélie / Carlos Lima / Christelle Chouzenoux / Inês Henriques / Inês Pinto Coelho / José Lima / Patrícia Carvalho / Tiago Silva

2103 A antiga fortificação de Quelba / Khor Kalba (E.A.U.). Resultados de quatro campanhas de escavações, problemáticas e perspectivas futuras Rui Carita / Rosa Varela Gomes / Mário Varela Gomes / Kamyar Kamyad

2123 Colónias para homens novos: arqueologia da colonização agrária fascista no noroeste ibérico Xurxo Ayán Vila / José Mạ . Señorán Martín 


\title{
A IGREJA DE SÃO LOURENÇO (MOURARIA, LISBOA): UM CONJUNTO DE SILOS E DE CERÂMICA MEDIEVAL ISLÂMICA
}

Andreia Filipa Moreira Rodrigues ${ }^{1}$

\begin{abstract}
RESUMO
A realidade arqueológica colocada a descoberto, em 1992 e 1993, na igreja de São Lourenço, situada Mouraria, em Lisboa, revelou uma ampla diacronia de ocupação, que se traduz numa sequência de enterramentos atribuíveis à idade média e moderna, associados ao espaço de culto; mas também, num conjunto de quinze silos que, de acordo com o espólio exumado do seu interior, se enquadram no período medieval islâmico, sendo anteriores à edificação da igreja.

Desta feita, pretende-se dar a conhecer a componente artefactual cerâmica que foi exumada do interior das estruturas de armazenamento, o seu significado e que relação possui este contexto com a realidade associada ao espaço de culto religioso, que se lhe sobrepõe.
\end{abstract}

Palavras-chave: Arqueologia, Lisboa, Silos, Cerâmica medieval islâmica.

\begin{abstract}
The archaeological context uncovered, in 1992 and 1993, in the church of São Lourenço, located in Mouraria, in Lisbon, revealed a wide diachrony of occupation, which translates into a sequence of burials attributable to the middle and modern age, related to the church; but also, in a set of fifteen silos that, according to the exhumed materials of its interior, fit into the medieval islamic period, being prior to the building of the church.

This time, it is intended to make known the ceramic artefactual component that was exhumed from the interior of the storage structures, its meaning and what relationship this context has with the reality associated with the religious cult space, which overlaps it.
\end{abstract}

Keywords: Archaeology, Lisboa, Silos, Medieval islamic ceramics.

\section{LOCALIZAÇÃO GEOGRÁFICA E CONTEXTUALIZAÇÃO HISTÓRICA}

A igreja de São Lourenço está localizada na junção entre a Rua do Marquês de Ponte de Lima, situada a Oeste, e o Largo da Rosa, que está a Sul; a Norte e Oeste está delimitada pelo Palácio da Rosa. Administrativamente, a igreja de São Lourenço começou por estar enquadrada da freguesia de São Lourenço, que seria substituída em 1886 pela freguesia de São Cristóvão e São Lourenço, para actualmente integrar a freguesia de Santa Maria Maior (SILVA, 1968, p. 186, 205, 240).

Os contextos colocados a descoberto com a intervenção arqueológica remetem para a Lisboa islâmica, sendo possível verificar a existência de duas reali- dades definidas pela muralha. De facto, no interior do perímetro muralhado desenvolveu-se a Medina, marcada pela Alcáçova, que surgia no ponto mais elevado. Fora de portas, surgiram os Arrabaldes Oriental e Ocidental, sendo neste último que se enquadra o sítio arqueológico da igreja de São Lourenço, mais concretamente no extremo Noroeste (SILVA, 1987a, p. 64, 183; SILVA, 2008, p. 79, 80, 85; BUGALHÃO, 2009, p. 384, 385, 388; SILVA, 2017, p. 234, 272; RODRIGUES, 2019, p. 6).

A conquista da cidade em 1147 provocou uma alteração de poderes e agentes políticos, que deixaram a sua marca ao restabelecerem a diocese, sacralizarem o espaço de culto e nomearem um novo bispo, Gilberto de Hastings. É ainda nesta altura que é fundado o espaço monástico de São Vicente de Fora

1. Arqueóloga; andreia93rodrigues@hotmail.com 
(BRANCO, 1996, p. 124, 125, 129; BRANCO, 1998, p. 57; RODRIGUES, 2019, p. 6). A par de todas estas transformações dá-se o movimento muito rápido de criação de freguesias associadas a espaços de culto cristão, que com o desenrolar do tempo vai perdendo força. De facto, é sabido que até 1191 eram 23 as igrejas paroquiais e que esta realidade não vai sofrer alterações até bem próximo da segunda metade do século XVI, que é quando se cria uma nova paróquia (SILVA, 1968, p. 189, 190; SILVA, 2012, p. 13; RODRIGUES, 2019, p. 7).

É, pois neste movimento que pode ser inserida a igreja de São Lourenço, ainda que existam algumas dúvidas acerca da sua data de fundação entre os investigadores (ARAÚJO, s.d., p. 64; ANDRADE, 1950, p. 181, 182; CASTRO, 1763, p. 329; MATOS, PORTUGAL, 1974, p. 145; GONÇALVES, SEGURADO, 1984, p. 37; SILVA, 1968; p. 186; BARROCA, 2000, p. 970; BOISSELLIER, 2002, p. 100; SILVA, 2008, p. 68, 253; RODRIGUES, 2019, p. 8).

Recentemente, surgiu uma hipótese que defende que quer a igreja, quer a freguesia, tenham sido criadas no ocaso do século XII, previamente a 1191 (FARELO, 2008, p. 249; SILVA, 2012, p. 13, 16). Esta datação alicerça-se numa fonte documental de 1346 , que mais não é do que uma cópia de um documento na qual se define "a divisão das igrejas da diocese entre o bispo e o Cabido de Lisboa em 1191, surgindo aí menção à igreja de São Lourenço já consagrada ao culto” (RODRIGUES, 2019, p. 8).

A igreja de São Lourenço teria tido um primeiro edifício do qual não se preservaram vestígios. Sabe-se de igual modo que foram sendo feitas modificações estruturais, que se traduziram na construção de 5 capelas góticas, fortemente afectadas durante os sismos de 1531 e 1755 (COELHO, 1998, p. 38; GONÇALVES, SEGURADO, 1984, p. 41-44; SILVA, 1995, p. 3).

Os danos provocados pelo sismo de 1531 foram de tal ordem que foi necessário instituir um imposto por forma a custear a reconstrução da igreja, que viria a ser reconstruída apenas no século seguinte. A par da reconstrução da igreja foi ainda construído o Palácio da Rosa que foi edificado no local onde outrora existiram as capelas góticas e ainda parte do local por onde passava a cerca Nova, que foi destruída. O terramoto de 1775 deixou também a sua marca e é referido inclusivamente a "queda de metade do tecto e de todo o coro” (GONÇALVES, SEGURADO, 1984, p.41-44; COELHO, 1998, p.38; AMARO, 2000, p. 2, 9; SILVA, 1995, p. 3; RODRIGUES, 2019, p. 9).
O dealbar do século XX traz consigo alterações no que ao urbanismo é referente, constatando-se, junto à igreja de São Lourenço, a abertura da Rua do Marquês de Ponte de Lima. Por fim, nos anos 70 da passada centúria os sinais de degradação da igreja e do palácio eram claros e tal facto levou a que a edilidade lisboeta se tornasse proprietária de ambos os edifícios (AMARO, 200o, p. 2; SILVA \& alli, 2014, p. 8; RODRIGUES, 2019, p. 9).

\section{A ESCAVAÇÃO ARQUEOLÓGICA}

A intervenção arqueológica realizada na igreja de São Lourenço enquadrava-se no âmbito de um projecto de requalificação do monumento, cujo intuito era consolidar a estrutura do edifício, desentulhar uma das capelas góticas e ainda alvitrar e efectuar o registo dos diversos enterramentos que existiam na igreja (AMARO, 20ooa, p. 2).

Deste modo, definiram-se doze sondagens das quais apenas se escavaram oito. As áreas intervencionadas foram distribuídas pelas várias zonas da igreja, tendo sido implantadas sondagens na nave central (sondagens 1 e 2), na primeira capela gótica (sondagens 3 a 6), num compartimento anexo à igreja (sondagem 7) e na segunda capela gótica (sondagem 8) (Figura 1) (AMARO, 200oa, p. 4-9; AMARO, 200ob, p. 1; RODRIGUES, 2019, p.10).

A estratigrafia detectada na Sondagem 1 corresponde a níveis de entulho e enterramentos. Esta realidade associada aos materiais recolhidos, como as moedas, e às estruturas colocadas a descoberto, como os muretes e o pavimento, permitiu antever a existência de várias fases da necrópole, cronologicamente balizada entre a idade moderna e a contemporaneidade (COELHO \& alii, 1999, p. 4, 5; AMARO, 200oa, p. 5-10; AMARO, 20oob, p. 2-6; Informações de Tiago Curado; RODRIGUES, 2019, p. 11, 12).

A escavação da Sondagem 2 revelou uma sequência de inumações, cronologicamente enquadrados entre a idade média e a idade contemporânea. Para além disso, colocaram-se a descoberto, estruturas como muretes de compartimentação da necrópole, um nível de pavimento e um conjunto de silos, os silos 1 a 4. Nos níveis de ocupação mais recentes foram recolhidas moedas. Relativamente aos silos, na sua grande maioria, os materiais exumados do seu interior remetem para o período medieval islâmico, excepção feita a uma destas estruturas onde para além de espólio desta cronologia surgiram igualmente ma- 
teriais atribuíveis aos séculos XV e XVI (AMARO, 200oa, p. 5-7; AMARO, 20oob, p. 2-6, 10; COELHO \& alii, 1999, p. 2, 11, 12; Informações de Tiago Curado; RODRIGUES, 2019, p. 12-15).

Nas Sondagens 3, 4 e 5 a estratigrafia observada é semelhante, tendo sido escavados níveis de entulho ulteriores ao terramoto de 1755 , que cobriam uma camada cronologicamente enquadrada entre a idade média e a modernidade. Nesta última camada, nas Sondagens 3 e 5 , as realidades mais recentes correspondem a enterramentos, de época moderna, e as mais antigas a silos, que integram o período medieval islâmico, de acordo com o espólio exumado. $\mathrm{Na}$ Sondagem 4 , a realidade mais recente desta segunda camada é referente a um nível de entulho enquanto a baliza cronológica mais recuada é atribuída a um conjunto de silos (COELHO \& alii, 1999, p. 13, 14; AMARO, 200oa, p. 7, 8; AMARO, 200ob, 7-11; Informação de Tiago Curado; RODRIGUES, 2019, p. 15-18). Quanto à Sondagem 6, a primeira camada detectada é referente a níveis de entulho resultantes do terramoto de 1755, conforme atestam os azulejos e moedas recolhidos. Num segundo momento colocaram-se a descoberto um ossário e enterramentos que são datados como sendo posteriores à segunda metade do século XVIII. Cronologicamente mais antigo, e atribuível à necrópole da idade média surge uma outra inumação feita no substrato rochoso (AMARO, 200oa, p. 7; AMARO, 200ob, 7, 8; Informação de Tiago Curado; RODRIGUES, 2019, p. 18).

Os trabalhos realizados na Sondagem 7 revelaram uma estratigrafia composta por uma camada de entulho posterior ao terramoto de 1755 , um conjunto de enterramentos associados a muretes de compartimentação da necrópole, cuja cronologia remonta à idade média, e quatro silos. Nos níveis mais recentes o espólio recolhido é composto por azulejos, moedas, faiança espanhola, parte de um pente em osso, medalhas em bronze ou um tubo de cachimbo. Já o enchimento dos silos forneceu materiais que podem ser enquadrados no período medieval islâmico (COELHO \& alii, 1999, p. 17-19; AMARO, 200oa, p. 8, 9; AMARO, 20oob, 13-16; Informação de Tiago Curado; RODRIGUES, 2019, p. 18-19).

A escavação encetada na Sondagem 8 forneceu poucas informações, sabendo-se apenas da existência de uma inumação, que foi escavada em parte, e de um silo cujo enchimento continha espólio atribuível ao período medieval islâmico (AMARO, 20ooa, p. 9; AMARO, 200ob, p. 16; RODRIGUES, 2019, p. 21).

\section{AS CERÂMICAS MEDIEVAIS ISLÂMICAS}

O estudo da componente artefactual exumada foi feito através da análise macroscópica dos materiais e das suas características que permitiram efectuar uma descrição pormenorizada, e posteriormente definir tipologias, 19 grupos de fabrico distintos e ainda identificar proveniências (RODRIGUES, 2019, p. 22).

O estabelecimento de uma tipologia e das formas que a integram teve em conta os diversos contributos que diversos autores aportaram ao longo dos anos (ROSSELLÓ-BORDOY, 1991; CATARINO, 1997/ 1998; GOMES, 2002; TORRES \& alii, 2003; GÓMEZ MARTINEZ, 2014; BUGALHÃO \& alii, 2010). Neste sentido, a tipologia definida é constituída pelos grupos da louça de mesa; louça de cozinha; vasilhames de armazenamento e transporte; materiais de construção; objectos lúdicos; contentores de fogo ou objectos de iluminação e os utensílios artesanais e agrícolas (Figura 2) (RODRIGUES, 2019, p. 28).

No grupo da louça de mesa cuja finalidade é a de servir alimentos para serem consumidos posteriormente, identificaram-se taças hemisféricas e carenadas, bilhas, jarras ou jarrinhas e jarros ou jarrinhos. De entre todas as formas detectadas as que têm maior expressão percentual são as jarras ou jarrinhas e as taças hemisféricas, por oposição às taças carenadas, aos jarros ou às bilhas que não são tão frequentes (RODRIGUES, 2019, p. 75, 76).

A aferição de paralelos nem sempre foi possível de ser efetuada para a totalidade do espólio exumado. As jarras provenientes da igreja de São Lourenço encontram paralelos em contextos de Lisboa, Santarém, Tavira ou Silves, e podem ser balizadas cronologicamente entre os séculos XI/XII e em alguns casos são idênticos a exemplares do século XIII (RODRIGUES, 2019, p. 41, 42, 63).

Para as taças hemisféricas existem semelhanças com peças de Lisboa, Santarém ou Palmela que podem ser enquadradas entre os séculos XI e XIII (RODRIGUES, 2019, p. 35-37, 63, 65, 68).

Já as taças carenadas encontram similitudes em contextos de Lisboa de cronologia compreendida entre os séculos XI e XII (RODRIGUES, 2019, p. 37-40, $63,65,67,68)$.

Para os jarros e as bilhas não foi possível proceder à sua integração cultural (RODRIGUES, 2019, p. 46). Dentro dos utensílios da louça de cozinha, que se destinam a confecionar os alimentos é possível 
encontrar panelas, tampas e alguidares. Neste conjunto é a panela a forma que está mais representa$\mathrm{da}$, contrastando com as tampas e os alguidares que estão presentes de forma menos significativa (RODRIGUES, 2019, p. 31, 75).

Algumas das panelas que foram exumadas dos silos da igreja de São Lourenço são em tudo idênticas a outros exemplares provenientes de Lisboa, Santarém, Palmela, Almada, Mértola ou Alcoutim e são atribuíveis cronologicamente aos séculos XI/XII, e XII/XIII (RODRIGUES, 2019, p. 32, 33).

Nos alguidares uma das peças recolhidas é semelhante a um exemplar oriundo do Núcleo Arqueológico da Rua dos Correeiros, cuja datação corresponde à segunda metade do século XII. Tal facto contrasta com outra das peças deste grupo que se insere num espectro cronológico mais lato compreendido entre os séculos VIII e XII (RODRIGUES, 2019, p. 32, 33, 63, 66, 68).

No caso das tampas não foram detectados paralelos formais ou cronológicos (RODRIGUES, 2019, p. 23 , $24,26,33)$.

Em termos de espólio exumado que pode ser enquadrado na categoria dos vasilhames de armazenamento e transporte apenas se identificaram formas como os cântaros e as talhas, cujo intuito é o transporte e o armazenamento quer de líquidos, quer de sólidos (RODRIGUES, 2019, p. 29-31,75).

Os cântaros são a forma que ocorre mais no registo arqueológico por oposição às talhas. Relativamente à existência de paralelos apenas os cântaros permitiram efectuar uma integração cultural. De facto, foi possível encontrar cântaros muito parecidos a algumas das peças da igreja de São Lourenço no Núcleo Arqueológico da Rua dos Correeiros inseridos do ponto de vista cronológico no século XI (RODRIGUES, 2019, p. 30, 31, 75).

Nos materiais de construção é possível englobar formas que têm como intuito a sua utilização no processo construtivo. Para os materiais da igreja de São Lourenço apenas se percepcionou a existência de telhas, que na ausência de elementos que as diferenciassem, não permitiu aferir cronologias (RODRIGUES, 2019, p. 46, 75).

Os utensílios que se enquadram na categoria dos contentores de fogo têm como objectivo a contenção do fogo, por forma a permitir a iluminação e ou o aquecimento. Dentro do contexto arqueológico estudado apenas se detectaram formas como o fogareiro ou o candil, não sendo possível estabelecer datações ou cronologias (RODRIGUES, 2019, p. 23 , $46,47,75)$.

Na série de objectos lúdicos surgem utensílios utilizados em actividades lúdicas ou rituais que no caso dos materiais estudados encontram repercussão em formas como as peças de jogo ou o tambor (RODRIGUES, 2019, p. 51, 52, 75).

Da totalidade das peças de jogo apenas duas forneceram algumas pistas em termos de datação, estando inseridas de uma forma genérica no século XI. De facto, estas formas resultam de reaproveitamentos de outras peças, que deixaram de desempenhar a sua função principal, e como se tratam de reutilizações afigurou-se difícil encontrar exemplares semelhantes (RODRIGUES, 2019, p. 52).

Quanto ao tambor não foi possível estabelecer cronologias ou até mesmo encontrar peças idênticas, devido as características do fragmento recolhido (RODRIGUES, 2019, p. 52).

Dentro da categoria dos utensílios ou instrumentos artesanais e agrícolas podem ser englobados objectos que servem para serem utilizados em trabalhos de cariz agrícola ou artesanal, tendo repercussão em formas como o cossoiro ou o bocal de poço (RODRIGUES: 2019, p. 48-51, 75, 76).

O cossoiro identificado é idêntico a um outro encontrado em Tavira que pode ser atribuído cronologicamente aos séculos XI e XII (RODRIGUES, 2019, p. 49).

O bocal de poço da igreja de São Lourenço encontra similitudes com uma peça proveniente de Beja, que tem uma gramática decorativa mais vasta. Para além disso, possui uma decoração que se repercute em fragmentos de talhas exumados em Tavira. Tendo em conta tudo isto, é possível defender que a cronologia desta peça se enquadra entre a segunda metade do século XII e a centúria seguinte (RODRIGUES, 2019, p. 51, 63).

De uma forma genérica o conjunto referente à louça de mesa é o que possui maior expressividade (58\%), por oposição ao grupo dos instrumentos artesanais ou agrícolas que é o menos representado (o,2\%) (Figura 3) (RODRIGUES, 2019, p. 71, 72).

Atentando na questão dos grupos de fabrico, foi possível dividir os fabricos em três grandes grupos: os fabricos 1, 10 e 6; os fabricos 2, 3, 4, 5, 7, 8, 9 e 11 a 13 e os fabricos 14 a 19 (RODRIGUES (2019, p. 22-25, 58). No primeiro conjunto, a dissonância reside essencialmente no ambiente de cozedura das peças. De facto, no fabrico 1 surgem peças onde é visível uma 
cozedura oxidante, no fabrico 10 uma cozedura redutora-oxidante e no fabrico 6 onde se evidencia um ambiente redutor. A aproximá-los estão aspectos como a presença de inclusões (reduzida a elevada), as pastas duras, que podem ser compactas a muito compactas, medianamente a muito homogéneas, a textura esponjosa e fractura irregular para além do torno rápido (RODRIGUES (2019, p. 22-25, 58).

O grupo composto pelos fabricos 2, 3, 4, 5, 7, 8, 9 e 11 a 13 apenas tem em comum as características da pasta que varia entre o pouco a muito homogéneo, pode ser compacta a muito compacta e tem inclusões de tamanho variável. Como factor diferenciador existe o ambiente de cozedura das peças que pode ser oxidante (fabrico 2 a 5), redutor, (fabricos 7 e 8), redutor-oxidante (fabricos 11 a 13), ou oxidante-redutor (fabrico 9). O torno e a dureza das pastas também diferem verificando-se a associação torno rápido e pastas duras (fabricos 2, 9 e 11); torno rápido e pastas brandas (fabricos 3,8 e 12), torno lento e pastas brandas (fabrico 4) e torno lento e pastas duras (fabrico 5,7 e 13). Para além de tudo isto a maior parte dos fabricos (fabricos 3, 4, 5, 7 a 9 e 12) possui uma textura esponjosa e fractura irregular contrastando com os casos em que isso não se verifica (fabrico 2, 11 e 13) (RODRIGUES (2019, p. 22-25, 58).

$\mathrm{O}$ último grupo assume algumas especificidades. Os fabricos 14 a 16 e 19 têm como principal traço marcante o facto de serem constituídos por peças feitas a torno rápido em que as pastas são duras, medianamente a muito homogéneas, medianamente a muito compactas, de textura esponjosa e fractura irregular, com grandes quantidades de elementos não plásticos e cozeduras oxidantes. Os fabricos $17 \mathrm{e}$ 18 são diferentes dos anteriores em termos dos ambientes de cozedura das peças e da homogeneidade das pastas. Assim, existem peças com cozedura redutora-oxidante e pastas muito homogéneas, contrastando com peças de cozedura redutora e pastas medianamente homogéneas (RODRIGUES (2019, p. 22-25, 58).

Em termos de proveniências foi possível constatar a presença de dois grandes grupos, as produções locais ou regionais, conjunto mais expressivo (96\%), e produções exógenas ou forâneas (4\%). Considerando os grupos de fabrico definidos e cruzando estes dados com as proveniências, foi possível alvitrar que as produções de cariz local ou regional se distribuem de uma forma esmagadora pelos grupos 1 , 10 e $6(76 \%)$, por oposição aos grupos 2, 3, 4, 5, 7, 8 ,
9 e 11 a 13, onde a sua presença não é tão significativa (20\%) (RODRIGUES, 2019, p. 22-25, 58).

Nas produções de carácter local e regional identificaram-se formas como a bilha, o cossoiro, o cântaro, o jarro, a jarra, a panela, a taça carenada, a taça hemisférica, a tampa, a peça de jogo, o alguidar, as talhas ou as telhas. No que concerne à gramática decorativa, este conjunto de peças pode ostentar pintura a branco, que é a mais representativa (conjuntos de 3 ou 4 riscas), a pintura a preto, ou ser desprovida de qualquer pintura. Para além da pintura verifica-se a aplicação de vidrados, de incisões e excisões, ou da digitação. Relativamente ao acabamento pode existir a aplicação de brunido (RODRIGUES, 2019, p. 58).

Para as as produções exógenas é possível enquadrar peças como o bocal de poço, uma peça de jogo, tampas e jarras, para além das panelas, que correspondem aos fabricos 14 a 19. Neste conjunto de peças apenas o bocal de poço, a peça de jogo e as taças carenadas e hemisféricas apresentam decoração. No bocal de poço está presente a combinação do vidrado e estampilhado, na peça de jogo é possível perscrutar a aplicação da corda seca, ao passo que nas taças hemisféricas e carenadas, que têm pastas de tonalidade laranja, foram pintados motivos a vermelho. As restantes formas identificadas não têm decoração, contudo fazem parte integrante deste grupo devido às suas pastas. Assim, tampas e as jarras possuem pastas de cor creme ao passo que as panelas têm pastas alaranjadas (RODRIGUES, 2019, p. $25,26,28,58,59)$.

\section{OS SILOS EM AL-UXBUNA}

Um silo é por definição uma estrutura de armazenamento, construída em profundidade e coberta por uma pedra, onde poderiam ser guardados alimentos secos que seriam posteriormente consumidos (RAMALHO \& alii, 2001, p. 150, 151; MALALANA UREÑA, MORÍN DE PABLOS; BARROSO CABRERA, 2013, p. 341).

Partindo deste prossuposto e tendo em conta informações, os relatórios referentes aos trabalhos arqueológicos desenvolvidos e ainda artigos de síntese acerca da prática arqueológica em Lisboa, onde para além de contextos de época islâmica se identificaram silos, foi possível aferir a existência de 116 silos, distribuídos por 26 locais. De facto, constata-se a presença de estruturas de armazenamento no 
espaço intra-muros, mas também no seu exterior (Figura 4) (BUGALHÃO, 2009, p. 388).

Dentro do perímetro muralhado foram detectados 5 conjuntos de silos na Medina e 6 na Alcáçova, perfazendo um total de 11. De todas as evidências identificadas na Medina apenas se contabilizaram este tipo de estruturas negativas em 2 locais, na Rua da Saudade (PRATA, 2014, p. 30) e no Teatro Romano (FERNANDES, 2013, p. 767).

Já para a Alcáçova o número de silos, 63, corresponde a todos os registos existentes. Morfologicamente, este tipo de estruturas podem apresentar forma piriforme (GOMES, GASPAR, 2000, p. 10, foto 10 e 11; (GASPAR, GOMES; 2001, p. 4-16; GASPAR, GOMES, 2013, p. 6-22, fig. 8; MIRANDA, 2013, p. 20, des. 5); ou sub-circular (SOUTA, LIMA, SARRAZOLA, 2012, p. 44, 50). Os dados existentes permitiram perceber que os silos sub-circulares coexistem no mesmo local onde também foram encontrados silos piriformes (GOMES, GASPAR, 2000, p. 10, foto 10 e 11; GASPAR; GOMES, 2001, p. 6-22; GASPAR, GOMES, 2013, p. 6-22, fig. 8; MIRANDA, 2013, p. 20) ou troncocónicos (FILIPE, 2011, p.14-16). Ainda na alcáçova existiram silos para os quais não foi possível saber a morfologia (GASPAR, GOMES, 1997, p. 23; GASPAR, GOMES, 2001, p.4-16).

No exterior do perímetro muralhado colocaram-se a descoberto 15 sítios com um total de 51 estruturas de armazenamento negativas. Destas, 5 estão situadas na parte ocidental da cidade e $5 \mathrm{em}$ Alfama.

No que é referente à forma, para além de estruturas de armazenamento sub-circulares (PEREIRA, 1924, p. 172, 173; RAMOS, JORDÃO, 1996/1997, fig. 32; SILVA, VALONGO, 2016/2017, p. 121), piriformes (AMARO, 200oa, p. 7; RODRIGUES FERREIRA, 2001, p. 51-53) e troncocónicos (AMARO, 200oa, p. 8, 9; RODRIGUES FERREIRA, 2001, p. 50), detectaram-se ainda silos bitroncónicos (AMARO, 200oa, p. 8, 9). Nestas três últimas morfologias é possível enquadrar os silos escavados na igreja de São Lourenço (AMARO, 200oa, p. 8, 9).

Ainda assim, importa mencionar os 37 silos para os quais a informação é escassa e que se distribuem pela alcáçova (GOMES, GASPAR, 2001, p. 8), medina (FERNANDES, 2013, p. 767; PRATA, 2014, p. 30); e arrabaldes (CALADO, LEITÃO, 2005, p. 462; RIBEIRO, 2012, p. 8; FERNANDES, 2009, p. 200; SILVA, 2014, p. 181; GOMES, SEQUEIRA, 2001, p. 105; RAMOS, JORDÃO, 1996/1997, p. 110-113; SALOMÉ, CALADO, 2012, p. 25).
Ainda nos arrabaldes existem sítios para os quais se sabe que existem silos mas não se sabe a sua quantidades, informação oral de Rodrigo Banha da Silva, a quem se agradece).

As diversas ocorrências de silos apuradas permitem perceber a sua dispersão quer dentro, quer fora do perímetro muralhado, sendo muito semelhante quer o número de núcleos de silos (11 zona intra-muros e 15 zona extra-muros), quer a quantidade de estruturas negativas identificadas ( 65 dentro do espaço muralhado e 51 no exterior da muralha).

De facto, a diferença reside quando se observa a alcáçova, a medina e os arrabaldes individualmente. No caso da alcáçova para um espaço relativamente diminuto existem uma grande quantidade de silos, cujo objectivo era o de garantir a sobrevivência das elites que estavam estabelecidas na Alcáçova.

Este aspecto contrasta de sobremaneira com o que se verifica na medina, em que dos 5 locais com silos apenas foram contabilizadas duas destas estruturas, algo que não se coaduna com a dimensão deste espaço e o número de pessoas que aqui residiam.

Fora de portas detectaram-se 15 sítios com um total de 51 silos. Destes, 36 estão disseminados por 6 locais no arrabalde ocidental, 11 pelo arrabalde oriental, correspondendo a 3 sítios, e apartado dos arrabaldes foram colocados a descoberto mais quatro silos. Tal como acontece na medina também nos arrabaldes existiram casos em que não se afigurou possível aferir o número de silos (2 no arrabalde oriental e 3 no arrabalde ocidental).

A cultura material exumada do interior dos silos deixa antever a presença de formas que podem ser encontradas em contextos habitacionais, como panelas, tampas, e alguidares, usados para a confecção de alimentos; taças hemisféricas e carenadas, bilhas, jarras ou jarrinhas e os jarros ou jarrinhos, nos quais eram consumidos os alimentos previamente preparados; para além dos cântaros e das talhas, usados para armazenamento e transporte. Acresce a toda esta panóplia formal a presença, ainda que menos expressiva, de candis e fogareiros, que serviam para iluminação e para cozinhar; de cossoiros, destinados às actividades de tecelagem; de tambores ou peças de jogo e do bocal de poço (RODRIGUES, 2019, p. 84,85$)$.

A alusão a silos, à sua existência, implantação, capacidade e funcionalidade, enquanto estruturas de armazenamento de alimentos para consumo da população, feita em fontes históricas, como a Cróni- 
ca da conquista de Lisboa aos Mouros, de Osberno (OLIVEIRA, SILVA, 1936, p. 81, 108) é enfatizada e reforçada com os vestígios arqueológicos colocados descobertos. Considerando a descrição presente nesta fonte, é possível fazer corresponder um dos locais e o conjunto de silos ao sítio onde foi construída a igreja de São Lourenço: “Encontraram-se depois no arrabalde, do nosso lado, e em cavernas abertas na encosta do monte, perto de cem mil cargas de trigo, cevada, milho e legumes, mantimentos da maior parte da cidade, porque ao sopé dos muros tinham grande extensão de espaço e a dureza da rocha forma para guardarem grande quantidade de objectos domésticos, ao passo que em baixo, no vale, a abundância das águas não lhes permitia abrir fossos" (OLIVEIRA, SILVA, 1936, p. 81).

Primordialmente estas estruturas destinavam-se a armazenar alimentos, mas quando deixaram de cumprir a sua função foram desactivadas e entulhadas com materiais e terra. Em Lisboa, através dos vestígios arqueológicos e nos casos em que foi possível perceber cronologias, verificou-se que a desactivação dos silos ocorreu paulatinamente, existindo estruturas de armazenamento que foram colmatadas mais tarde do que outras.

De facto, a primeira desactivação de silos ocorreu por volta dos séculos IX/X na Encosta de Sant'Anna (CALADO, LEITÃO, 2005, p. 468) seguindo-se os silos que foram detectados no Mosteiro de São Vicente de Fora que foram entulhados durante os X e XI (RODRIGUES FERREIRA, 2001, p. 49). Posteriormente no século XI dá-se a colmatação das estruturas presentes Fundação Ricardo Espírito Santo Silva (RAMOS, JORDÃO, 1996/1997, p. 110-112), tendo acontecido o mesmo no Largo das Portas do Sol (GOMES, SEQUEIRA, 2001, p. 105; SILVA, 2014, p. 181) e na Encosta de Sant'Anna (CALADO, LEITÃO, 2005, p. 468) em meados deste século.

Com a chegada do século XII mais um silo na Encosta de Sant'Anna deixa de armazenar alimentos (CALADO, LEITÃO, 2005, p. 468), tal como os silos descobertos na igreja de São Lourenço (RODRIGUES, 2019, p. 96) e no Palácio dos Condes de Penafiel, sítios inéditos, informação oral de Rodrigo Banha da Silva, a quem se agradece). Nas centúrias seguintes é no Palácio das Cozinhas do Castelo de S. Jorge, que são desactivados silos, 1, nos séculos XIII e XIV e mais 3 no século XV (FILIPE, 2011, p. 14-16). Por vezes, nem sempre é possível ter tanta clareza no estabelecimento das cronologias de desactivação dos silos conforme é patente numa das estruturas de armazenamento do castelejo do castelo de S. Jorge, em que apenas é mencionada uma datação posterior ao século XI (GOMES, GASPAR, 2001, p. 10); em 3 silos existentes na Encosta de Sant'Anna, colmatados em data anterior à edificação da Cerca Fernandina (CALADO, LEITÃO, 2005, p. 462); e num silo no Palácio das Cozinhas que terá sido entulhado entre o período islâmico e até ao século XV. No Beco do Forno, lote 40, foi possível detectar silos que foram cheios em dois momentos diferentes, século XI e séculos XV e XVI (GOMES \& alii, 2009, p. 957).

\section{CONCLUSÃO}

O sítio arqueológico da igreja de São Lourenço apresenta uma longa diacronia que vai desde o período medieval islâmico até à contemporaneidade. O espólio exumado do interior das estruturas de armazenamento permitiu aferir uma datação para a construção da igreja que se situa entre a segunda metade do século XI e a centúria seguinte, no máximo até pouco antes de 1191 .

Relativamente aos silos são estruturas que ocorrem em diversas urbes do al-Ândalus e a sua desactivação é um fenómeno paulatino que ocorre quando este tipo de estruturas deixa de servir o seu propósito inicial.

\section{BIBLIOGRAFIA}

ANDRADE, Ferreira de (1950) - A Mouraria: o Palácio da Rosa e os templos de S. Lourenço e do Coleginho [conclusão]. Olisipo. Revista do Grupo Amigos de Lisboa. Lisboa: 52, pp. 178-192.

AMARO, Clementino (20ooa) - Palácio Rosa - Igreja de São Lourenço (Mouraria - Lisboa). Relatório dos trabalhos arqueológicos. Relatório apresentado ao Instituto de Gestão do Património Arquitectónico e Arqueológico (IGESPAR).

AMARO, Clementino (20oob) - Caderno de Campo da Igreja de S. Lourenço. Relatório dos trabalhos arqueológicos. Relatório apresentado ao Instituto de Gestão do Património Arquitectónico e Arqueológico (IGESPAR).

ARAÚJO, Norberto (s.d.) - Peregrinações em Lisboa. Lisboa: s.e., vol. III.

BARROCA, Mário (200o) - Epigrafia Medieval Portuguesa (862-1422). Lisboa: Fundação Calouste Gulbenkian, 3 vols..

BOISSELLIER, Stéphane (2002) - Registres fiscaux et administratifs de bénéfices ecclésiastiques du royaume portugais XIII $-\mathrm{XIV}^{\mathrm{e}}$ siècles (Édition et présentation). Cotribution à l'étude du phénomène admnistratif. Memória inédita de 
habilitação para dirigir projectos de Investigação, Université Paris I-Sorbonne.

BRANCO, Maria João (1996) - A Conquista de Lisboa revisitada: estratégias de ocupação do espaço político, físico e simbólico. In $2^{\circ}$ Congresso Histórico de Guimarães: actas [Guimarães]. Guimarães: Câmara Municipal de Guimarães; Universidade do Minho, vol. 2, pp. 119-137.

BRANCO, Maria João (1998) - Reis, Bispos e Cabidos: A diocese de Lisboa durante o primeiro século da sua restauração. Lusitânia Sacra. Lisboa: 2ª série, tomo 10, pp. 55-94.

BUGALHÃO, Jacinta (2009) - Lisboa Islâmica: uma realidade em construção. Xelb. Silves: 9, pp. 379-393.

BUGALHÃO, Jacinta; CATARINO, Helena; CAVACO, Sandra; COVANEIRO, Jaquelina; FERNANDES, Isabel Cristina; GOMES, Ana; GÓMEZ MARTINEZ, Susana; GONÇALVES, Maria José; GRANGÉ, Mathieu; INÁCIO, Isabel; LOPES, Gonçalo; SANTOS, Constança (2010) - CIGA: Projecto de sistematização para a cerâmica islâmica do Gharb al-Andalus. Xelb. Silves, 10, pp. 455-476.

CALADO, Marco; SALOMÉ, Rita (2012) - Um Pequeno Conjunto Cerâmico de Época Medieval da rua de São Mamede (Lisboa). Al-Mandan. Almada: II, 1, pp. 23-30.

CALADO, Marco; LEITÃO, Vasco (2005) - A ocupação islâmica na Encosta de Sant'Ana (Lisboa). Revista Portuguesa de Arqueologia. Lisboa: 8,2, pp. 459-470.

CATARINO, Helena (1997/1998) - O Algarve Oriental Durante a Ocupação Islâmica - Povoamento rural e recintos fortificados. Al-'Ulyã, Revista do Arquivo Municipal de Loulé. Loulé, 6, 3vols.

COELHO, Teresa Campos (1998) - Trabalhos de Recuperação da Igreja de São Lourenço de Lisboa. Pedra \& Cal. Lisboa, 1, pp. 38-41.

COELHO, Teresa Campos; SILVA, José Custódio Vieira da; AMARO, Clementino; SABROSA, Armando; MONTEIRO, José Luís (1999) - Trabalhos de Recuperação da igreja de S. Lourenço de Lisboa-Conjunto de vestígios do período islâmico ao século XV. Comunicação apresentada no II Colóquio Temático Estudos de Lisboa - Séculos VIII - XV, Lisboa (trabalho inédito policopiado, consultado no Centro de Arqueologia de Lisboa).

FARELO, Mário (2008) - A Oligarquia Camarária de Lisboa (1325-1433). Lisboa. Tese de Doutoramento em História Medieval apresentada à Faculdade Letras da Universidade de Lisboa.

FERNANDES, Lídia (2013) - Teatro romano de Olisipo: a marca do novo poder romano. In ARNAUD, José; MARTINS, Andrea e NEVES, César, coord. - Arqueologia em Portugal. 150 Anos. Lisboa: Associação dos Arqueólogos Portugueses, pp. 765-773.

FERNANDES, Lídia (2009) - Capitel das Thermae Cassiorum de Olisipo (Rua das Pedras Negras, Lisboa). Revista Portuguesa de Arqueologia. Lisboa: 12, 2, pp. 191-207.
FILIPE, Victor (2011) - Projecto de ampliação e alterações para a Rua do Espírito Santo nº 31 - 35-ampliação da albergaria do Castelo de S. Jorge, Lisboa. Relatório apresentado à Direcção Geral do Património Cultural (DGPC).

GASPAR, Alexandra; GOMES, Ana; MENDES, Henrique Calé; PINTO, Paula; GUERRA, Sandra; RIBEIRO, Suzana; PIMENTA, João; VALONGO, António (2009) - Cerâmicas medievais provenientes do Beco do Forno - Castelo de S. Jorge. In ZOZAYA, Juan; RETUERCE, Manuel; HERVÁS, Miguel Ángel; JUAN, Antonio de (eds.), Actas del VIII Congreso Internacional de Cerámica Medieval en el Mediterráneo. Ciudad Real - Almagro del 27 de febrero al 3 de marzo de 2006, Tomo II, Ciudad Real, Asociación Española de Arqueología Medieval, pp. 955-962.

GOMES, Ana.; GASPAR, Alexandra.; Guerra, S.; VALONGO, António.; PIMENTA, João.; Pinto, P.; MENDES, Henrique.; Ribeiro, S. (2009) - A cerâmica vidrada da Alcáçova do Castelo de S. Jorge. In: ZOZAYA, Juan.; RETUERCE, Manuel.; HERVÁS, Miguel Ángel; JUAN, Antonio de (eds.), Actas del VIII Congreso Internacional de Cerámica Medieval en el Mediteráneo. Cuidad Real - Almagro del 27 de febrero al 3 de marzo de 2006, Tomo 1, Asociación Española de Arqueología Medieval, pp. 399-404.

GOMES, Ana; SEQUEIRA, Maria José (2001) - Continuidades e descontinuidades na arquitectura doméstica do período islâmico e após a conquista da cidade de Lisboa: Escavações Arqueológicas na Fundação Ricardo Espírito Santo Silva. Arqueologia Medieval. Porto, 7, pp. 103-110.

GOMES, Rosa Varela (2002a) - Silves (Xelb), Uma cidade do Gharb Al-Andalus: território e cultura. Lisboa: Instituto Português de Arqueologia (Trabalhos de Arqueologia, 23).

GOMES, Ana; GASPAR Alexandra; PIMENTA, João; VALONGO, António; PINTO, Paula; MENDES, Henrique; RIBEIRO, Susana; GUERRA, Sandra (2001) - A cerâmica pintada de época medieval da Alcáçova do Castelo de S. Jorge. In Garb. Sítios Islâmicos do Sul Peninsular (Sítios Islámicos del Sur Peninsular). Lisboa: Ministério da Cultura, Instituto Português do Património Arquitectónico Departamento de Estudos (IPPAR/DE), Junta de Extremadura - Consejaría de Cultura, pp. 119-163.

GÓMEZ MARTINEZ, Susana (2014) - Cerâmica Islâmica de Mértola. Museu de Mértola. Mértola: Campo Arqueológico de Mértola.

GONÇALVES, António Manuel, SEGURADO, Jorge (1984) - O Largo da Rosa e do Nobre Sítio de São Lourenço. Lisboa: Academia Portuguesa da História.

MALALANA UREÑA, Antonio; MORÍN DE PABLOS, Jorge; BARROSO CABRERA,Rafael (2013) - Acerca de la funcionalidad de los denominados "silos-basureros": una propuesta metodológica para el estudio de la agricultura andalusí en época califal y taifa. Archeologia Medievale. Firenze, XL, pp. 337-352. 
MIRANDA, Pedro (2013) - Intervenção arqueológica no Beco do Forno do Castelo nº $14-20$ - Muro (BFCM) Lisboa. Relatório apresentado à Direcção Geral do Património Cultural (DGPC).

OLIVEIRA, José Augusto de; SILVA, Augusto Vieira da (1936) - Conquista de Lisboa aos Mouros (1147). Lisboa: Serviços Industriais da Câmara Municipal de Lisboa.

PEREIRA, Félix Alves (1924) - Antiqvitvs: XXIII - Quatro "silos» ou celeiros encontrados no Chiado - Olaria portuguesa antiga - Covas dos mouros: sua antiguidade - A cêrca do Carmo. O Arqueólogo Português. Lisboa: $1^{\underline{a}}$ série, vol. XXVI, pp. 171-178.

PRATA, Sara (2014) - Relatório Final: Acompanhamento arqueológico - Recuperação de um edificio na Rua da Saudade, $n^{o}$ 2, 2 a e $2 b$ (Lisboa) - Relatório apresentado à Direcção Geral do Património Cultural (DGPC).

RAMALHO, Maria; LOPES, Carla; CUSTÓDIO, Jorge; VALENTE, Maria João (2001) - Vestígios da Santarém islâmica - Um silo no Convento de S. Francisco. Arqueologia Medieval. Porto: 7, pp. 147-168.

RAMOS, Rita; JORDÃO, Patrícia (1996/1997) - Relatório dos trabalhos arqueológicos realizados na Fundação Ricardo Espírito Santo - Lisboa (Campanhas de 1996 e 1997). Relatório apresentado ao Instituto Português de Arqueologia (IPA).

RIBEIRO, Nuno (2012) - Relatório Final, Beco da Cardosa - Ramais 33 e 35. Projecto de implantação de Gás Natural. Relatório apresentado à Direcção Geral do Património Cultural (DGPC).

RODRIGUES FERREIRA, F. E. (2001) - Os silos medievais de S. Vicente de Fora. Arqueologia e História, 53 (Estudos de Lisboa - séculos VIII-XV - II Colóquio Temático), Lisboa, Associação dos Arqueólogos Portugueses, Edições Colibri, pp. 49-66.

RODRIGUES, Andreia (2019) - Nos arrabaldes de al-Uxbuna: a ocupação islâmica no sítio arqueológico da igreja de São Lourenço (Mouraria, Lisboa). Dissertação de Mestrado em Arqueologia apresentada à Faculdade de Ciencias Sociais e Humanas da Universidade Nova de Lisboa.

ROSSELLÓ-BORDOY, Guillem (1991) - El Nombre de las Cosas en Al-Andalus, Una Propuesta de Terminología Cerámica. Palma de Mallorca: Museo de Mallorca.

SOUTA, Ana Rita; LIMA, Joana; SARRAZOLA, Alexandre (2012) - Relatório Final dos Trabalhos Arqueológicos. Sondagens de Diagnóstico Arqueológico Rua do Recolhimento 35 / Beco do Leão, Lisboa. Relatório apresentado à Direcção Geral do Património Cultural (DGPC).

SILVA, Augusto Vieira da (1968) - Dispersos. Lisboa: Câmara Municipal de Lisboa.

SILVA, Augusto Vieira da (1987a) - A Cerca Moura de Lisboa. Estudo Histórico Descritivo. Lisboa: Câmara Municipal de Lisboa.
SILVA, Augusto Vieira da (1987b) - A Cerca Fernandina de Lisboa. Lisboa: Câmara Municipal de Lisboa.

SILVA, Vítor (1995) - Igreja de S. Lourenço, na Mouraria Consolidação da estrutura. Jornal Arquitectos, no 147, pp. 54-55.

SILVA, Carlos Guardado da (2008) - Lisboa Medieval. A organização e a estruturação do espaço urbano. Lisboa: Colibri.

SILVA, Gonçalo (2017) - Ennoblecimiento, Saber y Poder: Las bibliotecas de las capillas de los Nogueira (1296-1464). In A. Suárez González (Ed.), Escritura y sociedad: La Noble$z a$. Santiago de Compostela, Instituto de Estudos Medievais (IEM), pp. 367-382).

SILVA, Gonçalo (2012) - Espiritualidade e Poder na Lisboa dos Finais da Idade Média: a Colegiada de São Lourenço e os seus Patronos (1298-1515). Lisboa. Tese de Mestrado em História - Área de Especialização em História Medieval apresentada à Faculdade de Ciências Sociais e Humanas da Universidade Nova de Lisboa (Policopiada).

SILVA, Manuel (2017) - Mutação Urbana na Lisboa Medieval. Das Taifas a D. Dinis. Tese de Doutoramento em História - Área de especialização em História Medieval apresentada à Faculdade de Letras da Universidade de Lisboa.

SILVA, Rodrigo Banha da, VALONGO, António (2016/2017) - A Urbanística do Subúrbio Ocidental de Felicias Iulia Olisipo (Lisboa): Um Contributo da I.A.U. da Rua do Ouro n.os 133-145. Cira Arqueologia. Vila Franca de Xira: 5, pp.116-148.

SILVA, Rodrigo Banha da (2014) - Intervenção arqueológica urbana de 1993 na Fundação Ricardo Espírito Santo Silva/ Largo das Portas do Sol (Lisboa): as evidências do período romano. Cira Arqueologia. Vila Franca de Xira: 4, pp. 178-199.

TORRES, Cláudio; GOMÉZ MARTINEZ Susana; FERREIRA, Manuela B. (2003) - Os Nomes da Cerâmica Medieval. Inventário de Termos. In III Jornadas de Cerâmica Medieval e Pós- Medieval - Métodos e Resultados para o seu Estudo (Tondela, 1997). Porto: Câmara Municipal de Tondela, pp. 125-134. 
Igreja de S. Lourenço

Bairro da Mouraria - Lisboa

Planta Geral

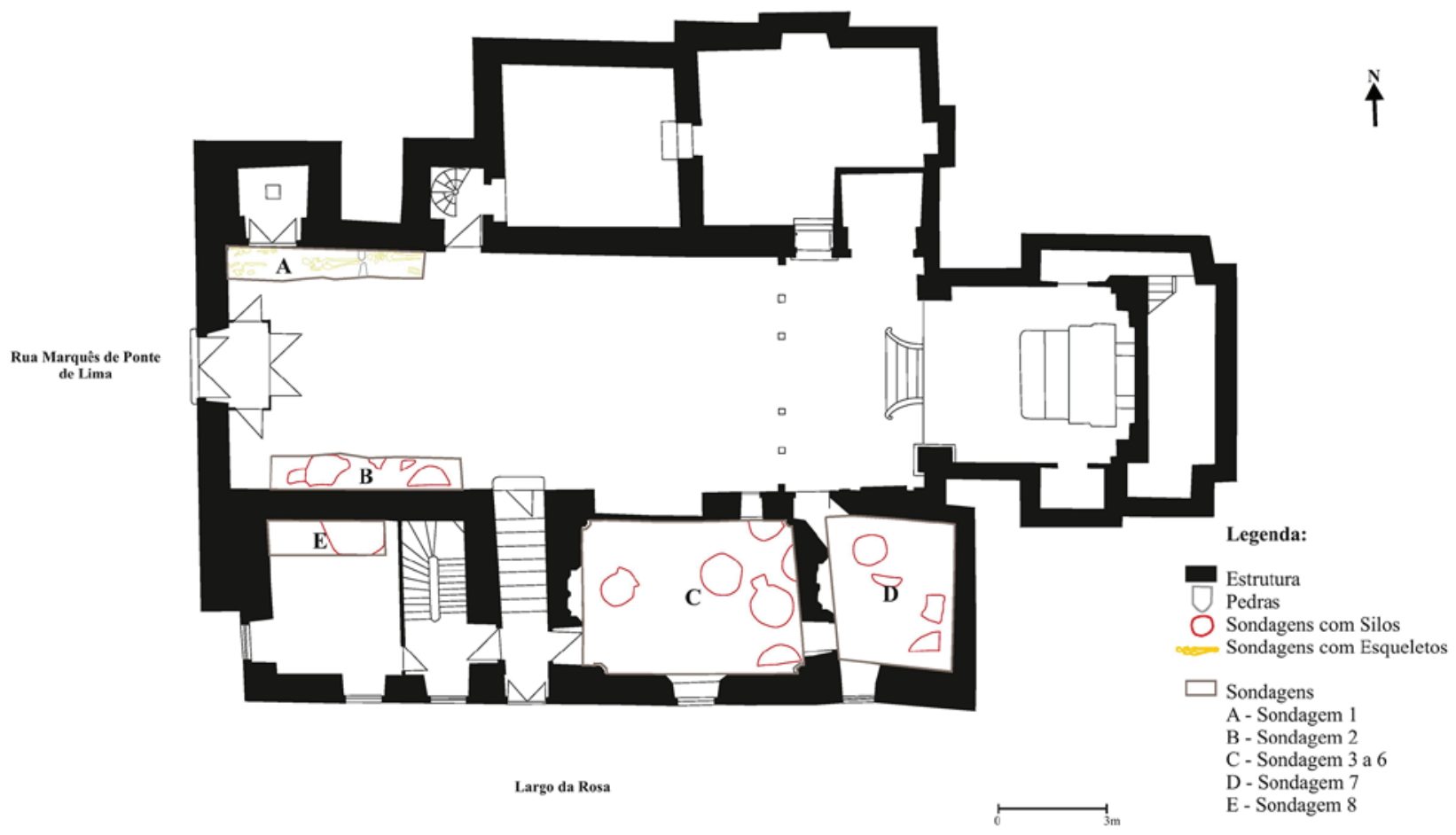

Figura 1 - Planta Geral da Igreja de S. Lourenço (AMARO, 200o, Figura 3, adaptado).

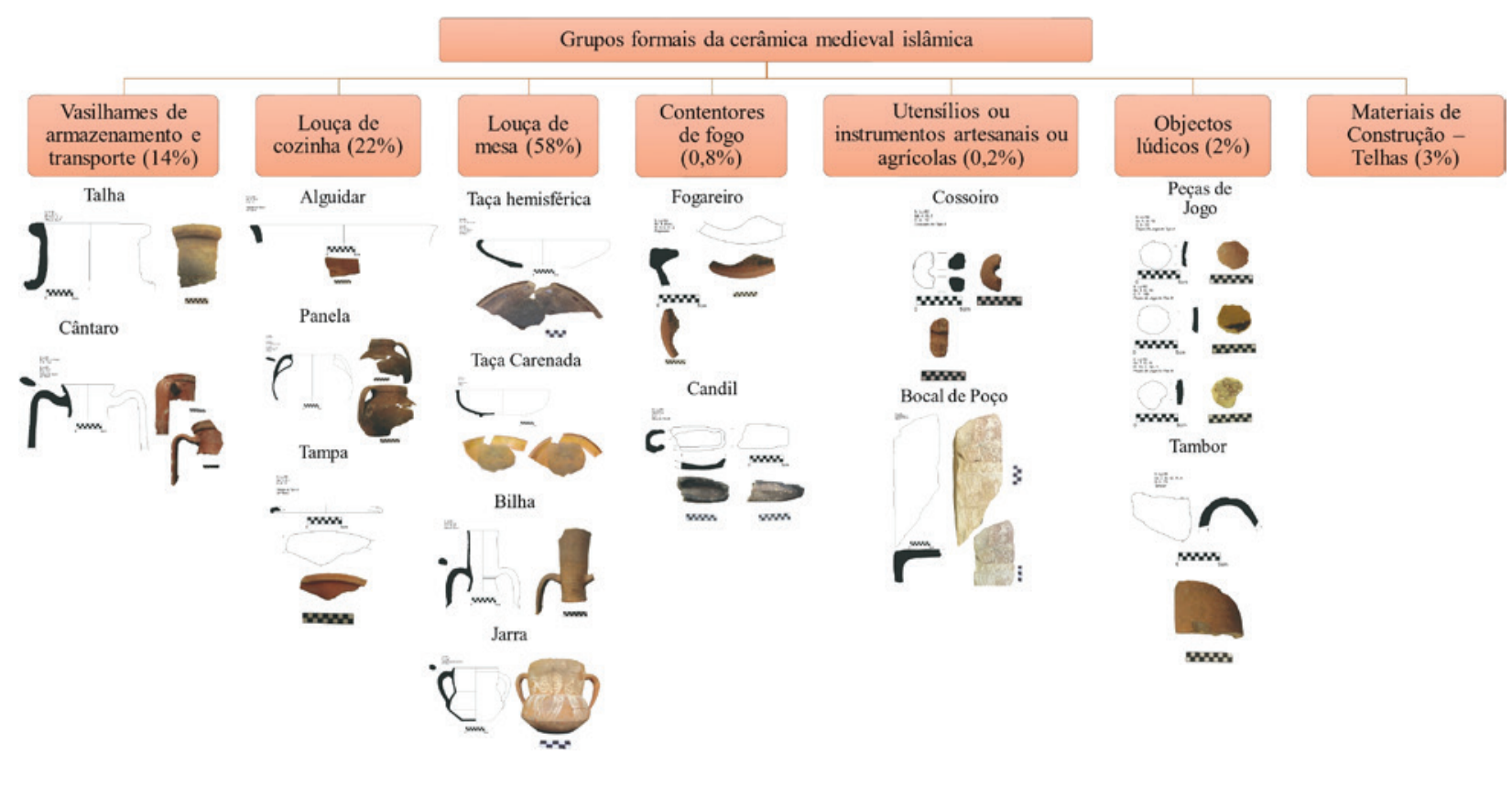

Figura 2 - Grupos formais da cerâmica medieval islâmica e a sua representatividade. 


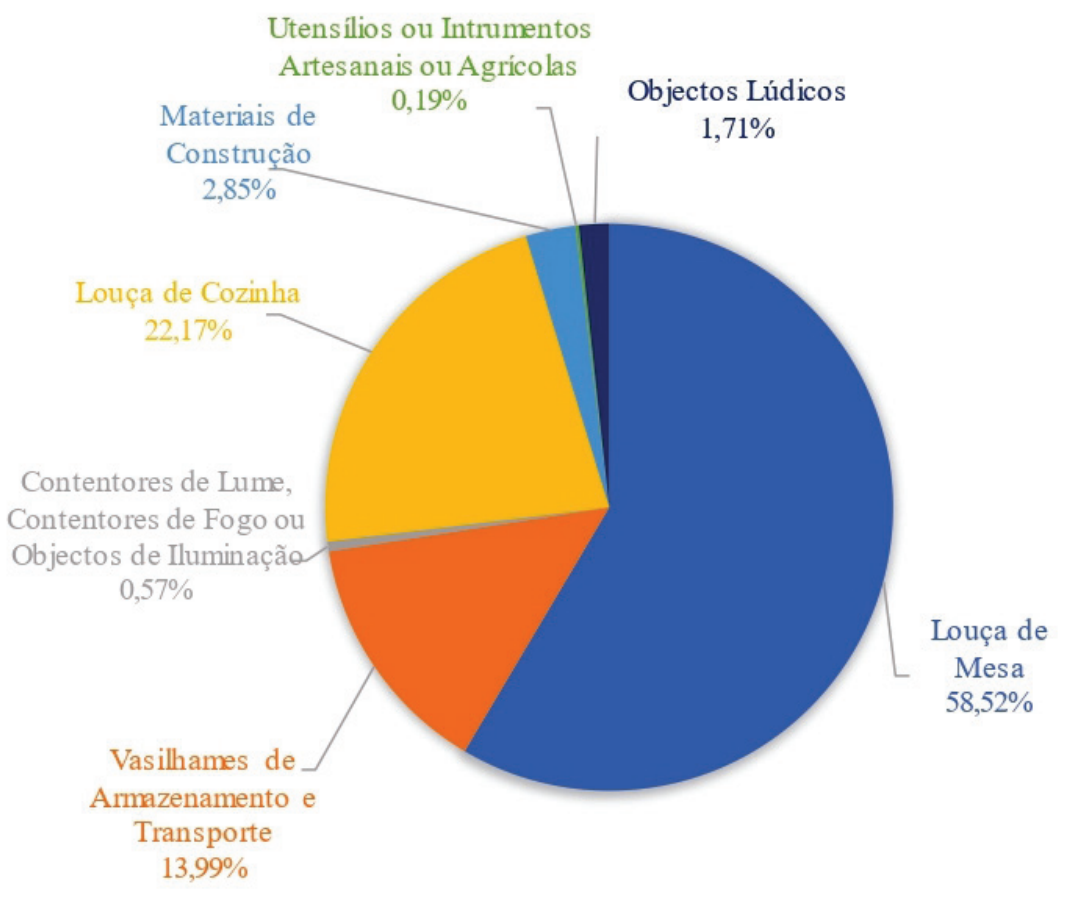

Figura 3 - Categorias tipológicas e respetivos percentuais.

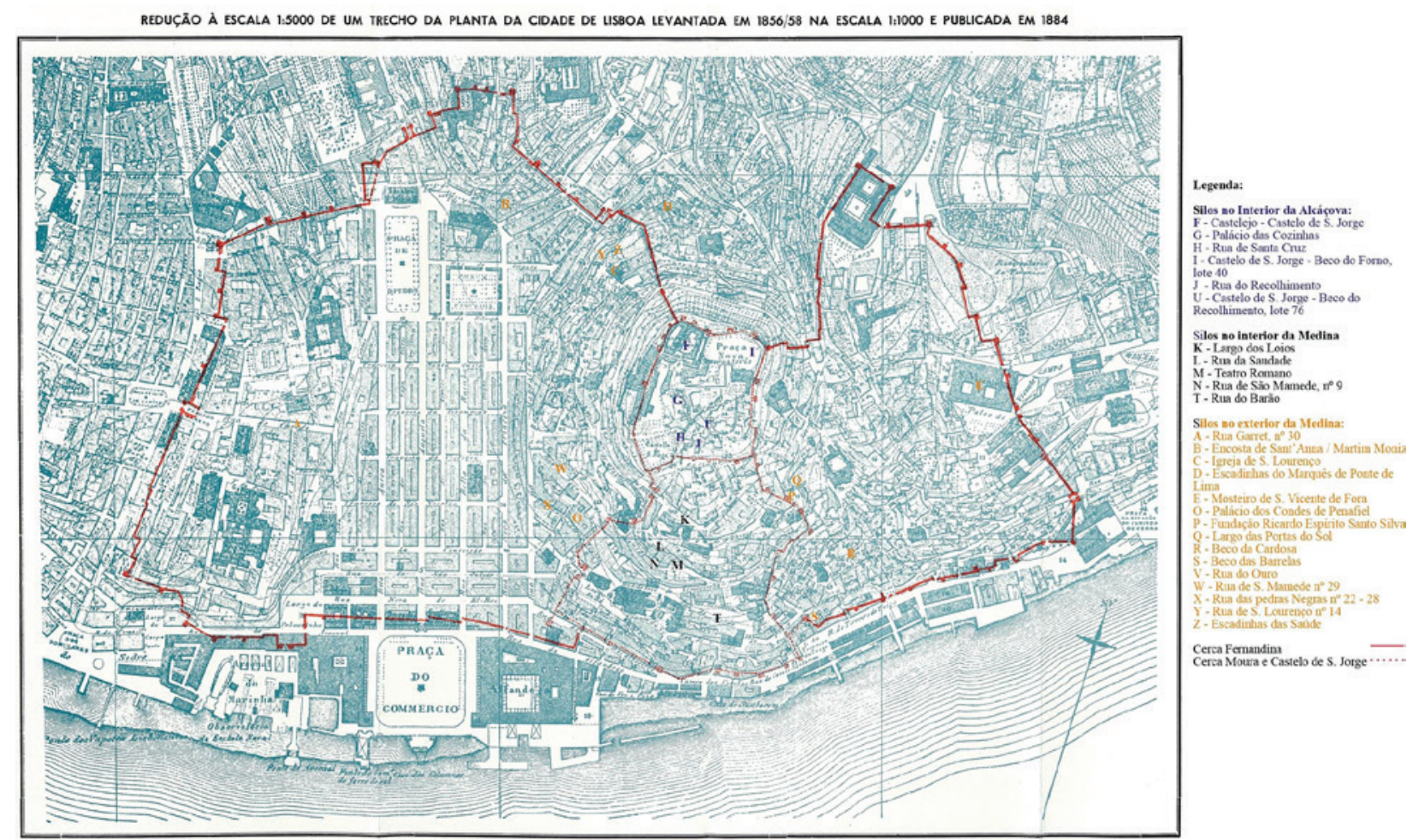

Figura 4 - Planta da cidade de Lisboa publicada em 1884 (SILVA, 1987b, adaptado) sobre a qual foram assinalados os locais que registaram a ocorrência de silos. (SILVA, 1987b, adaptado). 


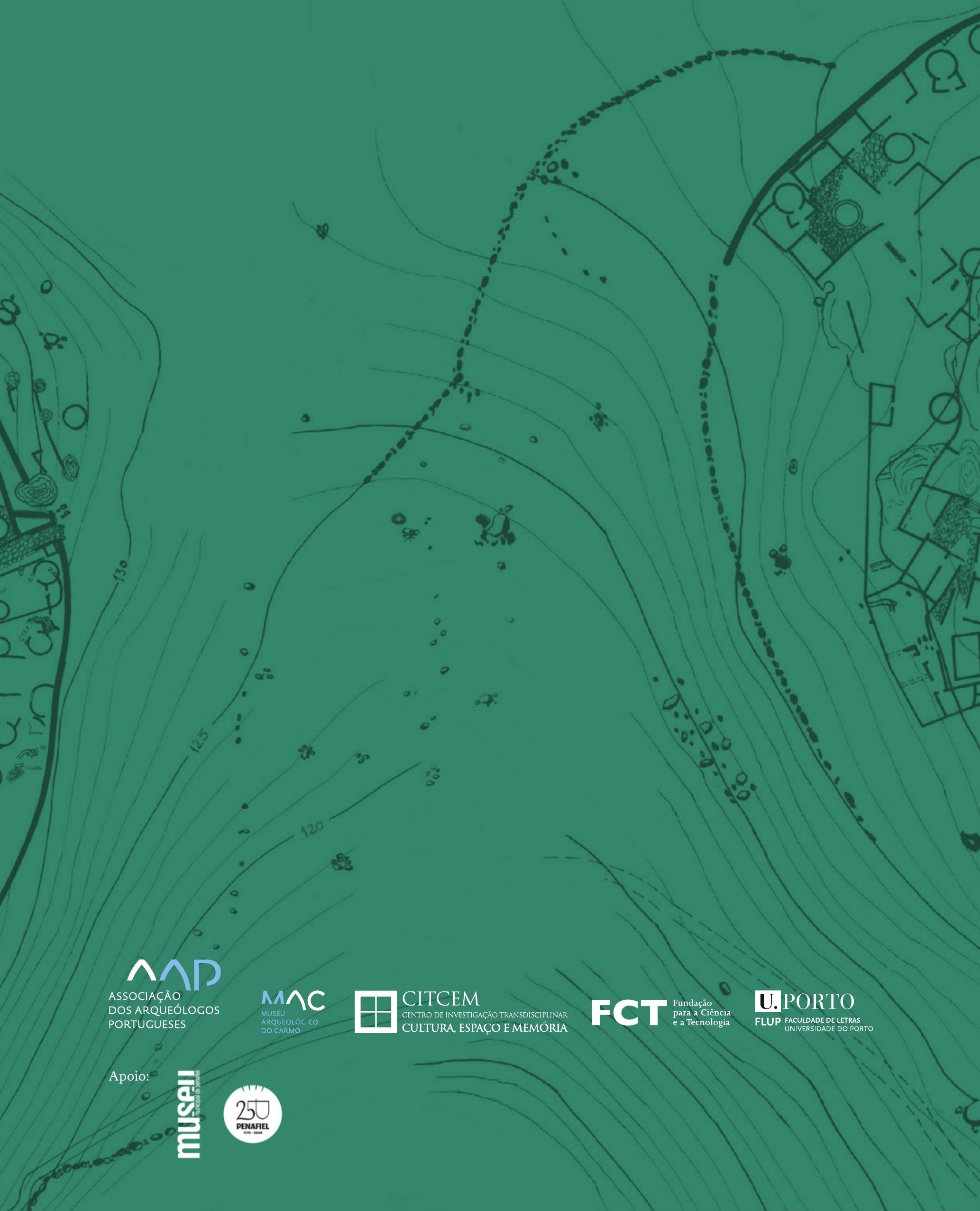

